\title{
Author Correction: Stress gates an astrocytic energy reservoir to impair synaptic plasticity
}

\author{
Ciaran Murphy-Royal (D, April D. Johnston, Andrew K. J. Boyce, Blanca Diaz-Castro, Adam Institoris, \\ Govind Peringod, Oliver Zhang, Randy F. Stout, David C. Spray, Roger J. Thompson, Baljit S. Khakh, \\ Jaideep S. Bains (i) \& Grant R. Gordon (1)
}

Correction to: Nature Communications https://doi.org/10.1038/s41467-020-15778-9, published online 24 April 2020.

The original version of the Supplementary Information associated with this Article contained an error in the Supplementary Data 2 file, which arose during manuscript preparation. The values in column D were sorted in descending order, but columns A-C were not reordered accordingly. The HTML has been updated to include the correct Supplementary Data 2 file.

Published online: 11 June 2020

\begin{abstract}
(c) (i) Open Access This article is licensed under a Creative Commons Attribution 4.0 International License, which permits use, sharing, adaptation, distribution and reproduction in any medium or format, as long as you give appropriate credit to the original author(s) and the source, provide a link to the Creative Commons license, and indicate if changes were made. The images or other third party material in this article are included in the article's Creative Commons license, unless indicated otherwise in a credit line to the material. If material is not included in the article's Creative Commons license and your intended use is not permitted by statutory regulation or exceeds the permitted use, you will need to obtain permission directly from the copyright holder. To view a copy of this license, visit http://creativecommons.org/licenses/by/4.0/.
\end{abstract}

(C) The Author(s) 2020 